PSIKOPEDAGOGIA, Vol. 1, No. 1, Juni 2012

ISSN: 2301-6167

\title{
HUBUNGAN KECEMASAN SOSIAL DAN KEMATANGAN EMOSI DENGAN KEMATANGAN SEKSUAL REMAJA SMP DI KABUPATEN BANTUL YOGYAKARTA
}

\author{
RELATIONSHIPS SOCIAL ANXIETY AND EMOTIONAL MATURITY \\ WITH SEXUAL MATURITY REMAJASMP \\ IN BANTUL YOGYAKARTA
}

Endang Sri Lestari, M. Si.

Fakultas Psikologi Universitas Ahmad Dahlan

\begin{abstract}
Abstrak
Penelitian ini bertujuan untuk mengetahui beberapa faktor yang berhubungan dengan kematangan seksual, seperti kecemasan sosial dan kematangan emosional pada remaja di SMP di Kabupaten Bantul, Yogyakarta. Hipotesis yang disajikan dalam penelitian ini adalah: Pertama; ada hubungan antara kecemasan sosial dan kematangan emosional terhadap kematangan seksual; Kedua, ada hubungan negatif antara kecemasan sosial dan kematangan seksual; Ketiga, ada hubungan positif antara kematangan emosi dan kematangan seksual. Para peserta penelitian yaitu 70 remaja pria dan wanita di SMP N 2 Banguntapan, Kabupaten Bantul. Pengumpulan data dilakukan dalam dua tahap, pertama, dengan menerapkan teknik area sampling untuk menentukan lokasi penelitian dan Kedua, dengan menerapkan cluster teknik random sampling untuk menentukan subjek sampel penelitian. Sementara itu, instrumen penelitian yang digunakan adalah skala kecemasan sosial, kematangan emosional dan kematangan seksual remaja. Teknik double-regresi diterapkan untuk menganalisis data dalam penelitian ini. Hasil penelitian ini menunjukkan bahwa: Pertama, ada hubungan antara kecemasan sosial dan kematangan emosional terhadap kematangan seksual pada remaja di SMP Kabupaten Bantul, Yogyakarta $(R=0.667, R 2=0.445$, F-regresi $=$ 26.911 dan tingkat signifikan sekitar $p<0,01)$. Kedua, ada hubungan negatif antara kecemasan sosial dan kematangan seksual pada remaja di SMP di Kabupaten Bantul, Yogyakarta $(R$ parsial = $0.632, p=0,01)$. Ketiga, ada hubungan positif antara kematangan emosi dan kematangan seksual pada remaja di SMP di Kabupaten Bantul, Yogyakarta $($ R parsial $=0358$, tingkat $p<0,01)$.
\end{abstract}

Kata kunci: kematangan seksual, kecemasan Sosial,kematangan Emosional.

\section{Abstract}

This research aims to find out some factors related to the sexual maturity, such as the social anxiety and emotional maturity on the adolescents of the SMP in Kabupaten Bantul, Yogyakarta. The hypotheses which are presented in this research are: First; there is a relation between the social anxiety and emotional maturity towards the sexual maturity; Second, there is a negative relation between the social anxiety and sexual maturity; Third, there is a positive relation between the emotional maturity and sexual maturity.The research participants were 70 male and female adolescents in SMP N 2 Banguntapan, Kabupaten Bantul. The data gathering was carried out in two phases, First, by applying the sampling area technique in order to determine the research location and Second, by applying the cluster random sampling technique to determine the research sample subject. Meanwhile, the research instrument which was employed was the scale of social anxiety, emotional maturity and sexual adolescents maturity. The double-regression technique was applied to analyze the data in this research.The result of this research showed that: First, there was a relation between social anxiety and emotional maturity towards the sexual maturity in adolescentsof the SMP in Kabupaten Bantul, Yogyakarta $\left(R=0,667, R^{2}=0,445, F-\right.$ regression= 26,911 and the significant level for about $p<0,01)$. Second, there was a negative relation between the social anxiety and sexual maturity in adolescentof the SMP in Kabupaten Bantul, Yogyakarta $(R$ partial=0,632, $p=0,01)$. 
Third, there was a positive relation between the emotional maturity and sexual maturity in adolescentsof the SMP in Kabupaten Bantul, Yogyakarta (R partial=0,358, level $p<0,01$ ).

Key words: sexual maturity, social anxiety, emotional maturity.

\section{PENDAHULUAN}

Kematangan seksual merupakan peristiwa kompleks yang melibatkan akumulasi proses fisik dan psikologi seseorang. Santrock (2002) mengungkapkan bahwa kematangan seksual adalah ciri utama perubahan pubertas yang mencakup sejumlah perubahan fisik dan psikologis. Munks (2006), menyebut perubahan-perubahan fisik ini sebagai ciri kelamin sekunder. Santrock (2002) menambahkan bahwa masa remaja bermula dari perubahan fisik yang cepat, perubahan bentuk tubuh dan perkembangan karakteristik seksual seperti pembesaran buah dada, perkembangan pinggang dan kumis dan dalamnya suara. Perkembangan pada masa ini ditandai dengan pencapaian kemandirian dan identitas diri yang sangat menonjol; peningkatan minat terhadap lawan jenis; pemikiran semakin logis, abstrak dan idealistis; dan semakin banyak waktu diluangkan di luar keluarga.

Kematangan seksual pada umumnya terjadi pada masa pubertas, yaitu usia 12-16 tahun pada anak laki-laki dan usia 11-15 tahun pada anak perempuan. Menurt Hurlock (1990) tahap ini ditandai dengan perubahanperubahan dalam pertumbuhan somatis dan perspektif psikologis. Selama periode ini, anak mengalami berbagai perubahan seperti perubahan dalam tubuh; perubahan dalam status termasuk penampilan, pakaian dan jangkauan pilihan; perubahan terhadap seks dan sikap terhadap lawan jenis.

\section{STUDI LITERATUR}

Beberapa ahli mengungkapkan, secara psikologis seseorang yang telah mencapai kematangan seksual ditandai dengan berbagai ciri, diantaranya adalah peningkatan minat terhadap citra tubuh, mampu menerima peranan dewasa berdasarkan pengaruh kebiasaan masyarakat sendiri, mendapatkan kebebasan emosional dari orangtua dan orang dewasa lainnya, mendapatkan pandangan hidup sendiri serta mampu merealisasi suatu identitas sendiri dan dapat mengadakan partisipasi dalam kebudayaan pemuda sendiri, pemikiran semakin logis, abstrak dan idealistis dan semakin banyak waktu diluangkan di luar keluarga.

Penelitian ini membatasi kajian kematangan seksual pada dimensi psikologis. Berdasarkan penjabaran-penjabaran di atas, maka disusunlah pengertian kematangan seksual. Kematangan seksual adalah tingkat penerimaan diri seorang remaja terhadap perubahan fisiknya di usia pubertas. Kematangan seksual lambat yang dimaksud dalam penelitian ini adalah mereka membutuhkan waktu penyesuaian yang lebih lama dalam menghadapi perubahan fisik pada usia pubertas, ditandai dengan sikap negatif dan penerimaan diri yang rendah seperti kurang percaya diri, rasa tidak puas dengan 
kondisi fisiknya dan belum berkembangnya minat terhadap lawan jenis. Kematangan seksual tinggi dicirikan dengan kemampuan yang baik dalam menyelesaikan tugas-tugas perkembangan yang dihadapi remaja pada periode pubertas, sebaliknya kematangan seksual rendah dicirikan dengan kemampuan yang rendah dalam menyelesaikan tugas-tugas perkembangan pada periode pubertas. Sebagaimana yang diungkapkan oleh Hurlock (1990), bahwa terlambat matang artinya memerlukan waktu yang lebih lama untuk menyelesaikan tugas-tugas perkembangan selama periode pubertas. Orang yang telambat matang lebih sulit beradaptasi secara psikologis terhadap perubahan fisik yang dialaminya pada periode pubertas. Kematangan seksual rendah disebut juga terlambat matang sebaliknya kematangan seksual tinggi disebut juga cepat matang.

Secara umum, berbagai penelitian yang telah dilakukan sebelumnya menunjukkan bahwa faktor-faktor yang berhubungan dengan kematangan seksual meliputi kecemasan, perubahan emosi, konsep difi, budaya, kebiasaan keluarga, kondisi lingkungan sosial, dukungan sosial, ketegangan emosional yang berlangsung lama, pendidikan dan perkembangan media. Hasil penelitian Winarti (2003), menunjukkan bahwabeberapa kondisi psikologis yang mempengaruhi kematangan seksual meliputi konsep diri, budaya, kondisi emosi, dan kebiasaan keluarga. Faktor lainnya adalah kondisi lingkungan sosial, dukungan sosial, dan ketegangan emosional yang berlangsung lama (Hurlock, 1990).
Salah satu faktor yang dianggap memiliki pengaruh dominan terhadap kematangan seksual diantara beberapa faktor di atas adalah faktor kecemasan sosial dan kematangan emosi. Alasannya adalah kira-kira dua tahun sebelum remaja benar-benar matang seksual (ditandai dengan menarche pada perempuan dan pollution pada laki-laki), perubahan ciri skunder telah dimulai, remaja mulai mengalami perubahan fisik. Hal ini menyebabkan sebagian remaja merasa tidak puas dengan kondisi fisiknya, ditandai perasaan, cemas, tidak percayadiri, takut dan menarik diri dari lingkungannya. Hurlock (2003), mengungkapkan bahwa hanya sedikit remaja yang puas dengan perubahan tubuhnya.

Menurut Smith (1993) kecemasan sosial adalah kecemasan dalam bergaul dengan orang atau kelompok lain. Remaja yang memiliki tingkat kecemasan tinggi akan menunjukkkan munculnya reaksi-reaksi seperti penarikan diri dan ketegangan dalam situasi sosial. Penatikan diri meliputi sensitivitas, perasaan ditolak, ketidak-bahagiaan dan kurang percaya diri. Ketegangan dalam situasi sosial meliputi reaksi-reaksi fisik dalam situasi sosial dan kecemasan berada dalam situasi sosial. Menurut Manuaba (1998), kecemasan sebagai rangsangan melalui sistem saraf diteruskan ke susunan saraf pusat yaitu bagian otak yang disebut limbic system melalui transmisi saraf, selanjutnya mempengaruhi pembentukan hormon-hormon reproduksi, seperti FSH (Follicle Stimulating Hormone) dan LH (Luteneizing Hormone) yang mengendalikan ciri kelamin primer maupunsekunder. Produksi kedua hormon ini dipengaruhi oleh mekanisme 
umpan balik estrogen terhadap hipotalamus juga pengaruh dari luar seperti, cahaya, baubauan dan hal-hal psikologik seperti kecemasan dan kondisi emosional. Aswin (2009), mengungkapkan hal senada bahwa pada kondisi cemas hipotalamus akan merangsang korteks adrenal untuk memproduksi hormone kortisol (glukokortikoid) dalam jumlah besar. Tingginya kadar kortisol dalam darah akan menekan produksi hormon seksual bahkan dalam waktu yang lama dapat mengakibatkan infertilitas pada laki-laki maupun perempuan.

Kematangan emosi adalah suatu kondisi perasaan atau reaksi perasaan yang stabil terhadap suatu objek permasalahan sehingga untuk mengambil suatu keputusan atau bertingkah laku didasari dengan suatu pertimbangan dan tidak mudah berubah-ubah dari satu suasana hati ke dalam suasana hati yang lain, mampu menilai situasi secara kritis terlebih dahulu sebelum bereaksi secara emosional sehingga dapat mengekspresikan perasaan yang ada dalam diri secara yakin dan menunggu saat serta tempat yang lebih tepat untuk mengungkapkannya dengan caracara yang lebih dapat diterima. Mulyono (1997) mengungkapkan bahwa orang yang telah matang emosinya mempunyai karakteristik seperti, dapat menerima keadaan dirinya maupun keadaan orang lain, tidak impulsif dalam merespon stimulus dan dapat mengatur pikirannya untuk memberikan tanggapan terhadap stimulus yang mengenainya, dapat mengontrol emosi meskipun keadaan marah, dapat berng berpikir secara objektif, memiliki tanggung jawab, dapat berdiri sendiri, tidak mudah mengalami frustasi dan menghadapi masalah dengan penuh pertimbangan.

Menurut Hurlock (1990), penyakit, gizi yang buruk dan ketegangan emosi yang berlangsung lama akan memperlambat kernatangan seksual anak. Gunarsa (2000), menambahkan bahwa kematangan emosi yang dicapai para remaja, diperlukan untuk dapat berpikir dcwasa dalam menghadapi permasalahan perkembangan organ seksualnya sehingga keinginan mereka dapat tersalurkan dalam kegiatan yang positif dan bermanfaat bagi dirinya. Menurut Gerungan (2000), dengan kematangan emosi yang cukup, memungkinkan seseorang dapat berubah cara berpikirnya kearah lebih dewasa, dapat berpikir lebih positif dalam menyikapi maka perubahan fisik, psikologis dan tingkah lakunya.

Faktor-faktor tersebut diatas mempengaruhi tingkat kematangan seksual seseorang. Winarti (2003) melaporkan hasil penelitian mengenai tingkat kematangan seksual anak perempuan di Kecamatan Tunjungsari Kabupaten Sumedang Jawa Barat relative rendah. Hal ini dipengaruhi oleh factor konsep diri, budaya, kondisi emosi, dan kebiasaan keluarga. Hasil observasi terhadap 150 responden perempuan pada usia 13-15 tahun, sebanyak 33 responden (22\%) mengalami kematangan seksual lambat. Hasil temuan tersebut sejalan dengan kondisi umum yang ditemukan pada remaja SMP di Kabupaten Bantul melalui observasi pendahuluan, diketahui bahwa tingkat kematangan seksual mereka rendah. 
Melalui angket tentang sikap siswa terhadap perubahan fisik di masa pubertas, ditemukan bahwa tingkat penerimaan diri terhadap perubahan fisik mereka rendah. Sebagian menunjukkan sikap negatif seperti kurang percaya diri, merasa kecewa dengan perubahan fisiknya, merasa malu, cemas dan tidak puas terhadap keadaan fisiknya.

Berdasarkan uraian di atas dapat di susun rumusan bahwa, kematangan seksual merupakan fenomena psikologis yang mengacu pada tingkat penerimaan diri seseorang terhadap perubahan fisiknya di usia pubertas.

Tinggi rendahnya tingkat kematangan seksual seseorang dipengaruhi oleh beberapa faktor. Faktor yang dianggap memiliki pengaruh paling besar terhadap kematangan seksual adalah kecemasan sosial dan kematangan emosi. Kecemasan sosial tidak berbeda dengan kecemasan pada umumnya, hanya saja berlangsung pada situasi sosial. Seseorang yang memiliki kematangan emosi cukup, dapat mengenali gejala-gejala sebelum kecemasan muncul. Remaja merupakan individu yang rentan dengan kecemasan dan persoalan-persoalan emosi dalam menghadapi berbagai bentuk perubahan fisik pada masa pubertas. Fenomena ini menunjukkan sebuah indikasi bahwa kematangan seksual remaja SMP di Kabupaten Bantul berhubungan dengan kecemasan sosial dan kematangan emosi, maka diajukan penelitian dengan judul: Hubungan Kecemasan Sosial dan Kematangan Emosi dengan Kematangan
Seksual Remaja SMP di Kabupaten Bantul Yogyakarta.

\section{METODE PENELITIAN}

\section{Subjek Penelitian}

Pengumpulan data penelitian dilaksanakan pada tanggal 1 April dan 2 April 2011di SMP 2 Banguntapan, Kabupaten Bantul Yogyakarta. Siswa-siswa yang menjadi subjek penelitian adalah siswasiswi kelas 8A dan 8B. subjek penelitian memiliki usia 14 sampai dengan 15 tahun.

Pengambilan sampel dilakukan melalui dua tahap yaitu teknik area sampling untuk menentukan sampel lokasi penelitian, dilanjutkan dengan teknik cluster random sampling untuk menentukan subjek penelitian. Menurut (Azwar, 2007), cluster random sampling merupakan suatu teknik sampling yang melakukan randomisasi terhadap kelompok bukan terhadap subjek secara individual, sedangkan teknik area sampling menurutSugiyono (2009) merupakan suatu teknik pengambilan sampel berdasarkan daerah populasi yang telah ditetapkan. Teknik sampling daerah (area sampling) digunakan untuk menentukan sampel bila objek yang akan diteliti atau sumber data sangat luas.

Pelaksanaan pengambilan data untuk masing-masing kelas membutuhkan waktu sekitar 60 menit. Jumlah keseluruhan subjek penelitian adalah 70 orang siswa, dengan perincian 35 orang siswa berasal dari kelas $8 \mathrm{~A}$ dan 35 orang siswa berasal dari kelas $8 \mathrm{~B}$. Seluruh skala yang dikembalikan layak dianalisis karena diisi dengan lengkap, tidak rusak dan tidak ada jawaban yang kosong. 


\section{Instrumen Penelitian}

a. Skala Kecemasan Sosial

Kecemasan Sosial adalah adalah kecemasan dalam bergaul dengan orang atau kelompok lain, suatu bentuk rasa cemas yang diarahkan pada lingkungan sosialnya. Individu khawatir dirinya akan mendapat penilaian negatif dari orang lain, khawatir tidak mampu mendapat persetujuan dari orang lain serta takut melakukan perilaku memalukan di muka umum yang termanifestasi dalam dua bentuk yaitu penarikan diri dan ketegangan sosial.

Pengumpulan data kecemasan sosial menggunakan skala kecemasan sosial yang disusun oleh Suharmini (1998) dengan mengacu pada ciri kecemasan sosial yang diungkapkan oleh Watson \& Friend (Smith et al, 1983). Skala terdiri dari aitem-aitem favorableyang disusun dari 6 aspek kecemasan sosial yang disusun dalam proporsi sama, yaitu 4 aitem sensitifitas , 4 aitem perasaan ditolak, 4 aitem perasaan tidak bahagia, 4 aitem perasaan kurang percaya diri, 4 aitem reaksi fisik dan 4 aitem kecemasan berada dalam situasi sosial. Setiap aitem dalam skala kematangan seksual memiliki rentang skor antara 1 sampai 4. Subjek diminta untuk memberikan respon terhadap semua alternatif jawaban yang tersedia. Semakin tinggi skor yang diperoleh subjek berarti semakin tinggi tingkat kecemasan sosialnya dan sebaliknya semakin rendah skor yang diperoleh subjek berarti semakin rendah pula tingkat kecemasan sosialnya.
Uji daya diskriminasi aitem dan reliabilitas Skala Kecemasan Sosial dilakukan dengan menggunakan pendekatan konsistensi internal dan Cronbach's Alpha if Item Deleted. Batts indeks diskriminasi yang aitem yang digunakan untuk menguji skala ini adalah 0,25 . Uji daya diskriminasi pada Skala Kematangan Seksual dilakukan terhadap 60 aitem. Uji diskriminasi aitem tersebut menghasilkan 24 aitem sahih dengan koefisien reliabilitas Alpha (a) sebesar 0,893 dan indeks daya beda ahem yang bergerak dari 0,285 sampai 0,837 .

\section{Skala Kematangan Emosi}

Kematangan emosi adalah suatu kondisi perasaan atau reaksi perasaan yang stabil terhadap suatu objek permasalahan sehingga untuk mengambil suatu keputusan atau bertingkah laku didasari dengan suatu pertimbangan dan tidak mudah berubah-ubah dari satu suasana hati ke dalam suasana hati yang lain, mampu menilai situasi secara kritis terlebih dahulu sebelum bereaksi secara emosional sehingga dapat mengekspresikan perasaan yang ada dalam diri secara yakin dan menunggu saat serta tempat yang lebih tepat untuk mengungkapkannya dengan caracara yang lebih dapat diterima.

Pengumpulan data kematangan emosi menggunakan Skala Kematangan Emosi yang disusun peneliti dengan mengacu ciri kematangan emosi yang diungkapkan oleh Mulyono (1997). Skala terdiri dari aitemaitem favorable dan unfavorable yang disusun dari 5 aspek kematangan emosi dengan proporsi aitem sama yaitu dengan rincian 5 aitem stabilitas emosi, 5 aitem 
kontrol emosi, 5 aitem kemampuan menikmati sumber emosional yang baik, 5 aitem kemandirian dan 5 aitem sikap realistik terhadap kehidupan. Setiap aitem dalam Skala Kematangan Emosi memiliki rentang skor antara 1 sampai 4. Subjek diminta untuk memberikan respon terhadap semua alternatif jawaban yang tersedia. Semakin tinggi skor yang diperoleh subjek berarti semakin tinggi tingkat kematangan emosinya dan sebaliknya semakin rendah skor yang diperoleh subjek berarti semakin rendah pula tingkat kematangan emosinya.

Uji daya diskriminasi pada Skala Kematangan Emosi dilakukan terhadap 50 aitem. Uji diskriminasi aitem tersebut Menghasilkan 25 aitem yang sahih dengan koefisien reliabilitas Alpha (a) sebesar 0,877 dan indeks daya beda aitem yang bergerak dari 0,226 sampai 0,678 .

\section{Skala Kematangan Seksual}

Kematangan seksual adalah tingkat penerimaan diri seseorang terhadap perubahan fisik di masa pubertas. Pengumpulan data kematangan seksual menggunakan Skala Kematangan Seksual yang disusun oleh peneliti dengan mengacu ciri kematangan seksual yang diungkapkan oleh Santrock (2003) dan Havighurst (1967). Skala terdiri dari aitem-aitem favorable dan unfavorable yang disusun dari 6 aspek kematangan seksual dengan proporsi aitem sama yaitu dengan rincian yaitu dengan rincian 4 aitem peningkatan minat terhadap citra tubuh (body image), 4 aitem minat terhadap lawan lawan jenis, 4 aitem penerimaan peran dewasa berdasarkan pengaruh kebiasaan masyarakat sendiri, 4 aitem kebebasan emosional dari orangtua dan orang dewasa lainnya, 4 aitem pandangan hidup sendiri serta 4 'aitem kemampuan merealisasi suatu identitas sendiri dan mengadakan partisipasi dalam kebudayaan pemuda sendiri. Setiap aitem dalam Skala Kematangan Seksual memiliki rentang skor antara 1 sampai 4. Subjek diminta untuk memberikan respon terhadap semua altematif jawaban yang tersedia. Semakin tinggi skor yang diperoleh subjek berarti semakin tinggi tingkat kemantangan seksualnya dan sebaliknya semakin rendah skor yang diperoleh subjek berarti semakin rendah pula tingkat kematangan seksualnya.

Uji daya diskriminasi pada Skala Kematangan Seksual dilakukan terhadap 60 aitem. Uji diskriminasi aitem tersebut menghasilkan 24 aitem yang sahih.

Koefisien reliabitas Alpha (a) yang dihasilkan pada skala ini sebesar 0,831 dengan indeks daya beda aitem yang bergerak dan 0,266 sampai 0,577 .

\section{Prosedur Pelaksanaan Penelitian}

Sebelum memberikan alat ukur, peneliti memperkenalkan din terlebih dahulu. Peneliti kemudian menyampaikan bahwa peneliti sedang mengumpulkan data untuk tugas akhir dan ingin mengetahui beberapa hal tentang kehidupan remaja, oleh karena itu meminta bantuan siswa untuk mengisi skalaskala yang dibawa peneliti. Peneliti selanjutnya membagikan Skala Kecemasan Sosial. Sebelum siswa mengerjakan skala tersebut, peneliti meminta siswa membaca petunjuk cara mengisi Skala Kecemasan 
Sosial. Peneliti juga memberikan contoh singkat cara mengisinya. Siswa selanjutnya dipersilahkan untuk mulai mengisi skala setelah mereka memahami cara mengisinya. Setelah selesai mengisi Skala Kecemasan Sosial, siswa diberi waktu istirahat sekitar 5 menit, kemudiandiminta untuk mengerjakan Skala Kematangan Emosi dandilanjutkan Skala Kematangan Seksual setelah waktu istirahat selesai. Sebelum mengerjakan Skala Kematangan Emosi maupun Skala Kematangan Seksual, peneliti kembali meminta mereka membaca petunjuk cara mengisi skala dan memberikan contoh singkat cara mengisinya.

\section{HASIL DAN PEMBAHASAN}

Hipotesis penelitian yang diajukan dalam penelitian ini akan diuji dengan metode statistikparametrik. Analisis data dalam penelitian ini digunakan untuk mengetahui hubungan antara kecemasan sosial dan kematangan emosi dengan kematangan seksual remaja SMP di Kabupaten Bantul, Yogyakarta.

Pengujian hipotesis penelitian dilakukan secara kuantitatif dengan teknik analisis regresi ganda. Data diolah secara komputasi dengan bantuan program SPSS 16.0 for Windows Evaluation Version. Sebelum melakukan ujihipotesis, terlebih dahulu dilakukan uji normalitas dan uji linieritas.

Uji normalitas sebaran dilakukan terhadap tiga variabel penelitian, menghasilakan nilai kolmogorov Z (KS-Z) sebesar 1,020 dengan nilai $\mathrm{p}=0,249$ untuk variabel kematangan seksual, nilai kolmogorov Z (KS-Z) sebesar 1,663 dengan nilai $p=0,080 \quad(p>0,05)$ untuk variabel kecemasan sosial dan nilai kolmogorov Z (KSZ) sebesar 1,297 dengan nilai $\mathrm{p}=0,069$ untuk variabel kematangan emosi. Berdasarkan hasil analisis ini, maka dapat dikatakan bahwa sebaran data ketiga variabel tersebut adalah normal.

Uji linieritas menghasilkan sebesar 53,809 dengan $\mathrm{p}=0,000$ untuk variabel kecemasan sosial dengan kematangan seksual, nilai $F$ sebesar 12,229 dan nilai $\mathrm{p}=0,001$ untuk variabel kematangan emosi dan kematangan seksual. Berdasarkan hasil analisis ini maka dapat dikatakan bahwa hubungan antara variabel di atas adalah linier, oleh karena itu dapat dikenai analisis korelasi regresi ganda.

Hasil analisis regresi ganda diperoleh nilai $\mathrm{R}=0,667 ; \mathrm{R}$ square $=0,445 ; \mathrm{F}-26,911$ dengan taraf signifikaroi $\mathrm{p}=0,000(\mathrm{p}<0,001)$. Hal ini menunjukkan bahwa ada hubungan antara kecemasan sosial dan kematangan emosi dengan kematangan seksual pada remaja SMP di Kabupaten Bantul, Yogyakarta. Hipotesis pertama diterima.

Selanjutnya analisis korelasi parsial digunakan untuk menguji hubungan antara variabel kecemasan sosial dan kematangan seksual dengan Mengontrol pengaruh variabel kematangan emosi. Hasil analisis korelasi parsial menghasilkan nilai parsial sebesar0,632 dan $\mathrm{p}=0,000 \quad(\mathrm{p}<0,001)$. Hal ini menunjukkan bahwa terdapat hubungan negatif antara variabel kecemasan sosial dengan kematangan seksual pada remaja SMP di Kabupaten Bantul Yogyakarta 
padatarafsignifikansi $\quad \mathrm{p}<0,01 . \quad$ Hipotesis diterima. Hasil analisis korelasi parsial pada tahap selanjutnya untuk mengetahui hubungan kematangan emosi dengan kematangan seksual dengan mengontrol pengaruh variabel kematangan seksual, menghasilkan nilai $r$ parsial sebesar 0,358 dengan taraf $\mathrm{p}=0,001$ $(p<0,01)$. Hal ini menunjukkan bahwa terdapat hubungan positif antara kematangan emosi dengan kematangan seksual remaja SMP di Kabupaten Bantul, Yogyakarta pada taraf siginfikansi $\mathrm{p}<0,01$. Hipotesis diterima.

Peneliti juga menghitung nilai koefisien determinasi $\left(\mathrm{r}^{2}\right)$ dalam hubungan antara variabel-variabel di atas. Nilai koefisien determinasi menunjukkan sumbangan efektif pengaruh variabel independenterhadap variabel dependen. Besarnya sumbangan efektif kedua variabel bebas tercermin dalam harga koefisien $\mathrm{R}$ Square sebesar 0,445. Angka tersebut menjelaskan bahwa 44,5\% variasi dari kematangan seksual remaja dapat dijelaskan oleh variasi kecemasan sosial dan kematangan emosi, sedangkan $55,5 \%$ sisanya dijelaskan oleh sebab-sebab lain yang kemungkinan diidentifikasi dapat mempengaruhi kematangan seksual.

Hasil uji hipotesis penelitian menunjukkan diterimanya ketiga hipotesis penelitian yang diajukan oleh peneliti. Secara umum terdapat hubungan antara kecemasan sosial dan kematangan emosi dengan kematangan seksual remaja SMP di Kabupaten Bantul, Yogyakarta. Tinggi rendahnya kecemasan sosial dan kematangan emosi mejadi dua prediktor bagi tinggi rendahnya kematangan seksual remaja.
Terdapat hubungan negatif antara kecemasan sosial dengan kematangan seksual dan terdapat hubungan positif antara kematangan emosi dengan kematangan seksual remaja SMP di Kabupaten Bantul Yogyakarta. Semakin tinggi kecemasan sosial remaja maka akan semakin rendah kematangan seksualnya, sebaliknya semakin rendah kecemasan social remaja maka akan semakin rendah kematangan seksualnya. Semakin tinggi kematangan emosi remaja maka akan semakin tinggi kematangan seksualnya, sebaliknya semakin rendah kematangan emosi remaja akan semakin rendah kematangan seksualnya.

Diterimanya hipotesis-hipotesis penelitian di atas mendukung berbagai hasil penelitian yang dilakukan oleh para ahli sebelumnya mengenai faktor-faktor yang berhubungan dengan kematangan seksual. Penelitian Conger (1977) menemukan bahwa kondisi psikologis seperti kecemasan dan ketidakstabilan emosi akan mengganggu mekanisme kerja hormon reproduki yang berakibat pada terhambatnya kematangan seksual seseorang.

Kecemasan sebagai suatu rangsang diteruskan ke susunan saraf pusat yaitu bagian otak yang disebut limbic system melalui transmisi saraf. Selanjutnya akan diteruskan ke kelenjar-kelenjar hormonal (endokrin) sehingga Mengeluarkan sekret (cairan) neurohormonal menuju hifofisis melalui sistem prontal guna mengeluarkan gonodotropin dalam bentuk FSH (Folikel Stimulazing Hormone) dan LH (Leutinizing Hormone). Produksi kedua hormon ini 
dipengaruhi oleh mekanisme umpan balik estrogen terhadap hipotalamus juga pengaruh dari luar seperti, cahaya, bau-bauan dan halhal psikologik seperti kecemasan dan kondisi emosional (Manuaba,1998). Hal ini didukung oleh pendapat Aswin (2009), bahwa pada kondisi cemas hipotalamus akan merangsang korteks adrenal untuk memproduksi hormon kortisol (glukokortikoid) dalam jumlah besar. Tingginya kadar kortisol dalam darah akan menekan produksi hormon seksual bahkan dalam waktu yang lama dapat mengakibatkan infertilitas pada laki-laki maupun perempuan.Hubungan antara kecemasan sosial dengan kematangan seksual, dapat dilihat pada skema di bawah ini:

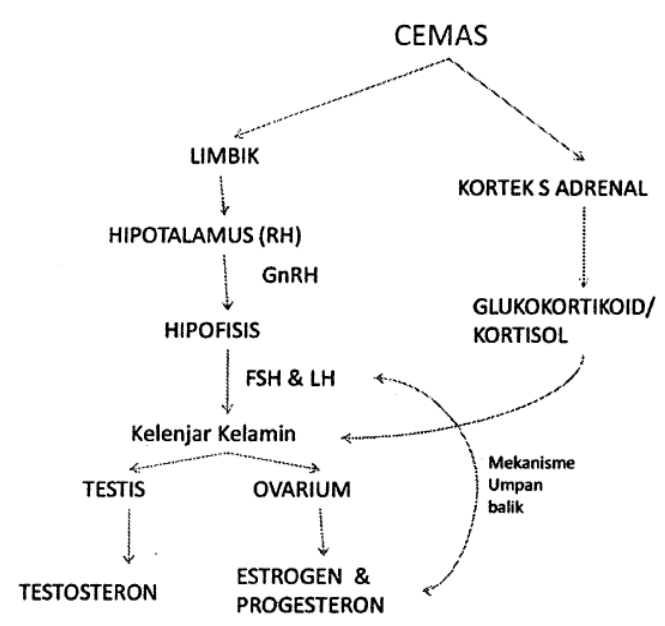

Gambar 1 :Pola Hubungan Antara Kecemasan Sosial dan Kematangan Seksual.

Faktor lainnya dalam penelitian ini yang mempengaruhi kematangan seksual seseorang adalah kematangan emosi. Temuan ini mendukung pendapat Hurlock (2000) bahwa kondisi lingkungan sosial, dukungan sosial, ketegangan emosional yang berlangsung lama dan konsep diri yang rendah pada remaja akan mempengaruhi kematangan seksual. Menurut Gunarsa (2000), kematangan emosi yang dicapai para remaja, diperlukan untuk dapat berpikir dewasa dalam menghadapi permasalahan perkembangan organ seksualnya sehingga keinginan mereka dapat tersalurkan dalam kegiatan yang positif dan bermanfaat bagi dirinya.

Hasil perhitungan koefisien determinasi menunjukkan bahwa selain kecemasan sosial dan kematangan emosi, masih terdapat faktorfaktor lain yang mempengaruhi kematangan seksual seseorang. Sumbangan faktor lain dalam mempengaruhi kematangan seksual sesorang sebesar 55,5\%.

Faktor-faktor tersebut sebelumnya telah diteliti oleh beberapa ahli. Winarti (2003), melaporkan hasil penelitiannya bahwa selain kondisi emosi, kematangan seksual juga dipengaruhi oleh beberapa faktor seperti konsep diri, budaya dan kebiasaan keluarga. Tonuabun (2008) dalam penelitiannya juga menemukan adanya hubungan yang signifikan antara indeks massa tubuh dengan usia menarche. Faktorlainnyaadalah hubungan orangtua dengan remaja, self esteem, tekanan negatif teman sebaya, religiusitas dan eksposur media pornografi (Soetjiningsih, 2004).

Sambas (2005) dan Abrar (2010) mengungkapkam bahwa perkembangan kematangan seks dipengaruhi visual informasi dari televisi yang ditangkap oleh anak-anak. Damarini (2001) menemukan hal senada, 
yaitu ada hubungan signifikan antara antara media cetak dan media eletronik dengan kematangan psiko seksual remaja. Reschousky dan Gerner (Faturochman, 1992) mengungkapkan bahwa munculnya perilaku seksual dapat dipengaruhi banyak faktor antara lain lingkungan tempat tinggal, orangtua, teman, sekolah, kurangnya informasi tentang masalah seksual, pergaulan bebas, larangan, buku-buku, majalah dan koran-koran. Soetjiningsih menambahkan bahwa pendidikan seksualitas dari lingkungan sekolah, keluarga dan masyarakat berkontribusi besar terhadap kematangan seksual remaja.

\section{KESIMPULAN}

Hubungan kecemasan sosial dan kematangan emosi dengan kematangan seksual remaja smp di kabupaten bantul yogyakarta menunjukan hasil yaitu pertama, ada hubungan antara kecemasan sosial dan kematangan emosional terhadap kematangan seksual pada remaja di smp kabupaten bantul, yogyakarta ( $\mathrm{r}$ $=0.667, \mathrm{r} 2=0.445, \mathrm{f}$-regresi $=26.911 \mathrm{dan}$ tingkat signifikan sekitar $\mathrm{p}<0,01)$. Kedua, ada hubungan negatif antara kecemasan sosial dan kematangan seksual pada remaja di smp di kabupaten bantul, yogyakarta $(\mathrm{r}$ parsial $=$ $0.632, p=0,01)$. Ketiga, ada hubungan positif antara kematangan emosi dan kematangan seksual pada remaja di smp di kabupaten bantul, yogyakarta $(\mathrm{r}$ parsial $=0358$, tingkat $\mathrm{p}$ $<0,01)$.

Secara umum terdapat hubungan antara kecemasan sosial dan kematangan emosi dengan kematangan seksual remaja
SMP di Kabupaten Bantul, Yogyakarta. Tinggi rendahnya kecemasan sosial dan kematangan emosi mejadi dua prediktor bagi tinggi rendahnya kematangan seksual remaja. Terdapat hubungan negatif antara kecemasan sosial dengan kematangan seksual dan terdapat hubungan positif antara kematangan emosi dengan kematangan seksual remaja SMP di Kabupaten Bantul Yogyakarta. Semakin tinggi kecemasan sosial remaja maka akan semakin rendah kematangan seksualnya, sebaliknya semakin rendah kecemasan social remaja maka akan semakin rendah kematangan seksualnya. Semakin tinggi kematangan emosi remaja maka akan semakin tinggi kematangan seksualnya, sebaliknya semakin rendah kematangan emosi remaja akan semakin rendah kematangan seksualnya.

\section{REFERENSI}

Abrar, A.R. (2010). Psikologi Pendidikan. Yogyakarta: Tiara Wacana.

Aswin. (2009). Psikologi Neurologi. Modul Kuliah. Yogyakarta: Fakultas Psikologi UAD.

Azwar, S. (2001) .Metodologi Penelitian:

Yogyakarta: Pustaka Pelajar.

Conger, J.J. (1977). Adolesence and Youth. Psychological Development in Changing World. New York: Happer and Row Publisher.

Gerungan. (2000). Psikologi Sosial. Bandung: PT Refika Aditama. Gunarsa, S.D. (1990). Dasar dan Teori Perkembangan Anak. Jakarta : PT BPK Gunung mulia. 
Hurlock, E. B. (2000). Psikologi Perkembangan Suatu Pendekatan Sepanjang Rentang Kehidupan. Edisi Kelima. Jakarta: Erlangga.

Hurlock, E. B. (1990). Perkembangan Anak. Jilid 2. Peneijemah: Meitasari Tjandrasa dan Muslichati Zakarsih. Jakarta: Erlangga.

Havighurst. (1967). Development Task and Education. New york: David McKay.

Manuaba. (1998). Seksualitas dalam Perspektif Psikologi Abnormal. Jakarta: Refika Aditama. '

Munks, F.J., Knoers, A. M. P., dan Haditono, S. R. (2006). Psikologi Perkembangan: Pengantar dalam Berbagai Bagiannya. Yogyakarta: Gadjah Mada University Press.

Mulyono. (1997). Pendekatan Analisis Kenakalan Remaja dan Penyimpangannya. Jakarta: Refika Aditama.

Sambas, R.I. (2005). Hubungan antara Perilaku Mengakses Situs Porno Internet dan Perilaku Seksual Pranikah pada Mahasiswa Universitas Diponegoro Semarang. Jurnal Psikologi UNDIP, 2, 60-74.

Santrock, J. W. (2002). Life Span Development. Perkembangan Masa Hidup. Edisi Kelima. Penerjemah: Shinto B. Adelar dan Sherly Saragih. Jakarta: Erlangga.

Santrock, J. W. (2003). Adolescence. Perkembangan Remaja. Penerjemah: Shinto B. Adelar dan Sherly Saragih. Jakarta: Erlangga.
Sugiyono. (2009). Metode Penelitian Pendidikan Pendekatan Kuantitatif, Kualitatif dan R\&D. Bandung: Alfabeta. Suharmini, T. (1998). Kecemasan Sosial Ditinjau Dari Konsep Diri dan Persepsi terhadap Remaja Awas pada Remaja Tunanetra di SLB/A Jawa Tengah dan Daerah Istimewa Yogyakarta. Tesis. Yogyakarta: Fakultas Psikologi Universitas Gajah Mada.

Toanubun, A. Y. (2008). Hubungan Indeks Masa Tubuh terhadap Usia Menarche pada Siswi SMPN 2 Tanjung Morawa Kecamatan Tanjung Morawa Kabupaten Deli Serdang Tahun 2008. Skripsi. Sumatra Utara: Fakultas Psikologi Universitas Sumatra Utara. 